\title{
"Talvez um dos Doze de Inglaterra (treze, na verdade, se a história estiver bem contada)" ou de como revisitar o cânone para reinventar outra narrativa: reflexões em torno de O Magriço, de Tiago Salazar
}

\section{Resumo:}

O presente trabalho tem como objetivo tecer algumas reflexões sobre o mais recente romance do escritor português Tiago Salazar, O Magriço (2020), procurando observar alguns pontos importantes na sua construção, desde a idéia lançada no subtítulo da obra ("A verdadeira história de D. Álvaro Gonçalves Coutinho, um dos Doze de Inglaterra") até à sua categorização genológica ("romance histórico"). Para tanto, os postulados de Maria de Fátima Marinho (1999), Mário César Lugarinho (2005) e Umberto Eco (1985), dentre outras fontes importantes, serão articulados para pensar de que forma o autor expande as fronteiras constitutivas da tipologia textual para compor um romance que revisita o cânone camoniano não só para reinventar uma outra narrativa, mas também para revelar a simplicidade e a dissidência de certos agentes históricos, pintados muitas vezes unicamente com tonalidades heroicas, bem como as suas amarguras e os seus dissabores.

Palavras-chave:

Romance histórico pós-moderno, Cânone camoniano, Novíssima ficção portuguesa, Tiago Salazar

\section{Abstract:}

The present work aims to reflect on the most recent novel by the Portuguese writer Tiago Salazar, 0 Magriço (2020), seeking to observe some important points in its construction, since the idea launched in the subtitle of the work ("The true story of D. Álvaro Gonçalves Coutinho, one of the Twelve of England") until its genological categorization ("historical novel"). Therefore, the postulates of Maria de Fátima Marinho (1999), Mário César Lugarinho (2005) and Umberto Eco (1985), among other important sources, will be articulated to think about how the author expands the constitutive boundaries of the textual typology to compose a novel that revisits the Camonian canon not only to reinvent another narrative, but also to reveal the simplicity and the dissidence of historical agents, often painted solely in heroic tones, as well as their bitterness and their unpleasantness.

Keywords:

Postmodern historical novel, Camonian canon, New Portuguese fiction, Tiago Salazar 
Esse texto é para Gabriela Silva, professora e investigadora que, nos últimos anos, vem dividindo comigo a paixão pelas novidades no cenário da ficção portuguesa. Citá-la, aqui, é uma forma de reconhecer o seu trabalho, bem como de agradecer a sintonia nos diálogos e nas partilhas de idéias.

No passado, podiam-se acusar os historiadores de querer conhecer somente as "gestas dos reis". Hoje, é claro, não é mais assim. Cada vez mais se interessam pelo que seus predecessores haviam ocultado, deixado de lado ou simplesmente ignorado. [...] As fontes não nos contam nada daqueles pedreiros anônimos, mas a pergunta conserva todo seu peso.

(Carlo Ginzburg, o queijo e os vermes)

É assim, no ato de emendar a História que o ficcionista intervém, não porque acredite apenas que à ficção não cabe o resgate do referencial, mas por um fato mesmo que lhe serve de a priori: o de que todo discurso - enquanto linguagem -, seja ele o discurso da História, estabelece com o referente uma lacuna irreparável.

(Teresa Cristina Cerdeira, Formas de ler)

Entre o facto e o fingido, não haveria de o facto ter mais apelo. Uma lenda podia saciar tanto ou mais o leitor ávido do que é mágico e não se explica, do que aquilo que não passa de uma coisa que já bem se conhece e apenas se lhe ver mérito de estar esta tão bem escrita, podendo até ser mentirosa.

[Tiago Salazar, O Magriço)

Quando, em 1984, José Saramago lança o seu romance $O$ ano da morte de Ricardo Reis, ele não apenas investe sua verve criadora na construção de um dos mais belos quadros sobre Fernando Pessoa e o contexto epocal das primeiras décadas do século XX, como também sublinha a canonicidade de um outro poeta português para onde todas as atenções da literatura e da cultura do seu país convergiam: Luís de Camões.

Assim, não é de forma gratuita que, pela voz do narrador, se ouve a sentença certeira de que "[...] todos os caminhos da literatura portuguesa vão dar a Camões, de cada vez mudado consoante os olhos que o vêem" (Saramago 2011: 198). Na verdade, tal postulado - o de que Camões constitui um ponto nevrálgico e uma referência intertextual incontornável da/na literatura portuguesa, independentemente, da época ou da linhagem estética dos seus dialogantes - não se assenta num dado desconhecido pelos críticos literários e pelos estudiosos da cultura portuguesa, muito pelo contrário, já que, a própria condição de escritor canônico do autor de Os Lusíadas é sobejamente reconhecida. ${ }^{1}$

Essa reverberação do autor e da obra quinhentistas em cenários muito posteriores confirma a importância de Camões e d'Os Lusíadas nos diferentes movimentos estéticos portugueses, seja na condição de poeta canônico no campo literário, seja na de paradigma simbólico nos 
diferentes contextos culturais de língua portuguesa (Franco 2011). Assim, não será à toa a revisitação operada pelos diferentes sistemas literários lusófonos ao longo dos séculos sucedâneos sobre a figura do poeta e as por ele criadas e eternizadas nas páginas do poema épico.

No tocante à ficção portuguesa contemporânea, objeto de minhas investigações nos últimos anos, é interessante observar como Camões, Os Lusíadas e parte significativa de sua produção lírica surgem ora como vozes poéticas evocadas intertextualmente ao longo das malhas e das arquiteturas textuais, como ocorre, por exemplo, no já citado $O$ ano da morte de Ricardo Reis (1984), de José Saramago, ou em Pode um desejo imenso (2002), de Frederico Lourenço; ora como personagens e/ou como matérias recriadas pelas efabulações narrativas, como são os casos das obras de Jorge de Sena (no conto "Super flumina Babylonis", 1964), de António Lobo Antunes (no seu conhecidíssimo romance As naus, 1988), de Frederico Lourenço (no conto "O retrato de Camões", 2004), de Gonçalo M. Tavares (no anti-épico Uma viagem à Índia, 2010) e, mais recentemente, de Mário Cláudio (no romance Os naufrágios de Camões, 2016).

Nesse conjunto, onde outros nomes também caberiam, não deixa de ser significativo o fato de que boa parte dessa produção ficcional portuguesa seja estudada pelo viés do romance histórico pós-moderno (Arnaut 2002; Gobbi 2011; Marinho 1999). Muito diferente do seu homônimo, cultivado pelos escritores românticos no século XIX, tal categoria genológica diferencia-se do seu predecessor por um procedimento muito particular que a singulariza. Em seu denso ensaio, 0 romance histórico em Portugal, Maria de Fátima Marinho explica alguns pormenores dessa tipologia romanesca:

O repensar irónico pós-moderno da História revela-se definitivamente não nostálgico, ao contrário da evocação romântica de Idades Médias de sonho, na medida em que se toma plena consciência de que não há uma só verdade, facto que se poderá traduzir por uma grande instabilidade na focalização (Marinho 1999: 41)

Como se pode depreender da explicação acima, não estamos distantes dos ensinamentos de Umberto Eco, para quem as manifestações ficcionais pós-modernas reconhecem que o passado "não pode ser destruído porque sua destruição leva ao silêncio", por isso, ele "deve ser revisitado: com ironia, de maneira não inocente" (Eco 1985: 57). Ora, Maria de Fátima Marinho igualmente reconhece as ocorrências desses procedimentos em diferentes momentos da literatura portuguesa, juntamente com as suas múltiplas categorias efabulatórias, incluindo aí as sagas familiares, as biografias de personagens históricas e referenciais, a autobiografia fictícia e a própria metaficção historiográfica.

Na verdade, a aproximação entre os dois pólos discursivos em evidência compõe já um campo demasiadamente explorado e com uma fortuna crítica considerável, o que torna a proposta aqui desenhada mais desafiadora, afinal, o que haveria mais a se explorar sobre o diálogo entre a literatura e a história?

Ainda que o instrumental escolhido não seja uma novidade, acredito que alguns pressupostos teóricos podem ser relembrados e rearticulados para tecer uma série de reflexões em 
Cadernos de Literatura Comparada

"Talvez um dos Doze de Inglaterra (treze, na verdade, se a história estiver bem contada)"

torno do mais recente romance do escritor português Tiago Salazar²: O Magriço (2020) , cujo título, como bem se percebe, se debruça sobre a figura consagrada nos versos de Os Lusíadas, na conhecida passagem dos Doze de Inglaterra (Canto VI).

Reconhecido como um "repositório de matéria de cavalaria" (Ferro 2011: 320), o episódio dos Doze de Inglaterra surge n'Os Lusíadas como uma espécie de preparação dos portugueses, antes do enfrentamento de uma tempestade, motivada por Baco, na cena do concílio dos deuses marinhos. De forma geral, há um consenso de que Camões teria tomado a Relação ou Crónica Breve das Cavalarias dos Doze de Inglaterra, de Jorge Ferreira de Vasconcelos, supostamente datada pelo ano de 1550 (Basto 1986), como fonte primária para a criação da cena cavaleiresca.

Muito diferente, porém, do seu modelo motivador, a passagem dos doze portugueses que foram à Inglaterra, em socorro das damas difamadas por doze homens ingleses, ganha nos versos camonianos uma dimensão muito mais densa, com riquezas de detalhes nas descrições das batalhas e na vitória retumbante dos cavaleiros lusos. Aliás, o cuidadoso estudo de Artur de Magalhães Basto reitera a criação de Camões "com superior beleza e indiscutivelmente com maior interesse ou densidade dramática", comprovando-se ser fruto da "intervenção emocional de um artista" (idem: 9).

Vale ressaltar, no entanto, que ambos os textos (o de Camões e o de Vasconcelos) não exploram devidamente alguns pontos que permanecem obscuros, como, por exemplo, os antecedentes e o destino pós-batalha de uma personagem central desse episódio: a trajetória de Álvaro Gonçalves Coutinho, ou, simplesmente, Álvares Gonçalves Magriço, como é chamado na Relação ou Crónica Breve. Onde teria nascido? Qual a sua trajetória até se tornar cavaleiro? O que o teria levado a aceitar o desafio num outro país? Qual o destino do Magriço, depois de seu retorno da batalha?

Ainda que Veloso, na sua narrativa na épica camoniana, indique que o Magriço "Lá se deixou ficar, onde um serviço / Notável à Condessa fez de Frandes", além de "Outro também dos doze em Alemanha / Se lança" (Camões 2011: 236), fato é que essas questões povoam o projeto criador de Tiago Salazar, na medida em que aposta numa personagem secundária e com papel coadjuvante nas versões oficiais, cuja trajetória, quando aparece, tem um recorte muito específico, centrado unicamente na sua função de compor um conjunto de cavaleiros portugueses numa missão de resgate da honra alheia e no sucesso obtido na batalha. E, nesta nuance, a obra do jovem escritor português merece alguns destaques muito positivos.

Um aspecto muito sedutor no romance surge com a introdução de paratextos que convidam o leitor a entrar no jogo estabelecido desde o início. Se, realmente, estamos diante de um texto fruto da imaginação, o subtítulo aponta ironicamente para uma impossibilidade, pois, como construir uma "história verdadeira", se o gênero textual onde ela se desencadeará é uma matéria pura de efabulação, ou seja, um "romance histórico"? Aliás, essa incorporação histórica é preparada e reiterada a partir da conjugação de outras paratextualidades, a saber: a dedicatória, em forma de reverência a uma dama, valendo-se de uma estrutura poética muito cara às cantigas trovadorescas ("Para a mui nobre, distinta e formosa senhora / dos meus afectos / DONA MAIA ORNELAS / De cujos os encantos meu coração é cativo"; Salazar 2020: 5); as duas epígrafes citadas 
(uma retirada do Canto VI de Os Lusíadas, onde se expõe o desejo do Magriço em ir a Inglaterra por terra até onde pudesse; e outra de uma trova heráldica do Alcaide-Mor do Porto, João Rodrigues de Sá); um prólogo, em que Álvaro Gonçalves Coutinho se apresenta como um homem "nascido para ser guerreiro por não haver outra condição" (idem: 10) na sua linhagem, com todos os seus vícios e virtudes; uma pequena nota introdutória, em que a voz autoral expõe a presença salutar das incertezas e a impossibilidade de tudo poder narrar; e, por fim, no final, uma nota de "Agradecimentos" (idem: 189), com o reconhecimento explícito do autor ao verbalizar as suas fontes e os investigadores portugueses com quem estabeleceu contato para a feitura do romance.

Olhados em conjunto, esses pequenos paratextos sugerem um espírito inquieto do escritor na montagem do percurso do seu protagonista. Isto porque, ainda que se reconheça a sua honradez, o valor da palavra empenhada enquanto cavaleiro e a sua origem familiar, Álvaro Gonçalves Coutinho nunca havia se destacado, enquanto criatura ficcionalizada ou historicizada, como uma figura central, seja nos versos camonianos, seja na Relação ou Crónica Breve. Logo, acredito que, a partir dessa claudicância depositada sobre a figura do Magriço, não satisfeito com as informações obtidas nas "gestas dos reis" (Ginzburg 1985: 15) e no cânone camoniano, Tiago Salazar coloca-se num salutar gesto interrogativo, onde as suas perguntas pesam sobre as sombras deixadas nos atores secundários e coadjuvantes da história e das obras literárias por onde circulam.

Para tentar, portanto, burlar esse mistério sobre o Magriço e suas andanças pela Europa, antes e depois da batalha na Inglaterra, Tiago Salazar vale-se de um bem sucedido recurso na construção desse seu romance histórico: cria uma narrativa em que o próprio Álvaro Gonçalves Coutinho, já velho, preocupa-se em deixar registradas as suas memórias "nítidas e ditadas com esmero" (Salazar 2020: 19), mas sem cair nos velhos lugares-comuns das "lazeiras de cavalaria andante" (ibidem). Assim, ele conta em primeira pessoa todo o seu percurso, desde as suas origens familiares, os desafios enfrentados até se tornar cavaleiro, a sua ida a Inglaterra e as etapas posteriores ao grande embate, até a sua velhice.

Na verdade, O Magriço, enquanto romance histórico, tal como anunciado na capa da edição portuguesa, pode ser inserido na categoria de "autobiografia fictícia" (Marinho 1999: 215), ou seja, como uma obra ficcional em que o próprio herói assume a $1^{\mathrm{a}}$ pessoa, contando os fatos significativos de sua trajetória (ibidem). No entanto, longe de se tratar de uma categoria simplória para narrar uma história, como bem adverte Maria de Fátima Marinho, "o género da autobiografia fictícia é, pois, um caso específico no seio do romance histórico, uma vez que o facto de a narração ser assumida pela própria personagem cuja biografia se quer relatar tem implicações várias" (idem: 217). No caso da obra de Tiago Salazar, uma dessas implicações reside exatamente naquilo que Michal Glowinski designa como o "paradoxo da narração":

By the paradox of narration, I mean the following phenomenon: starting the story, the narrator possesses an absolute knowledge of its subject, but reveals it step by step, not right away. The narrator suggests that the story develops in a parallel way to the sequence of events described. (Glowinski 1977: 105) 
Cadernos de Literatura Comparada

"Talvez um dos Doze de Inglaterra (treze, na verdade, se a história estiver bem contada)"

Ora, tal artimanha narrativa pode ser constatada já na estrutura romanesca, subdivida em três partes, correspondendo exatamente aos três espaços de circulação do narrador-protagonista: "I - Nas Terras Altas" (Salazar 2020: 15), "II - Na Borgonha" (idem: 105) e "III - No Reguengo do Aro de Lamego" (idem: 157). Mesmo sabedor do evento principal no percurso do Magriço, de certo modo, o leitor adere ao pacto estabelecido pelo narrador autodiegético, no momento em que compreende a necessidade de não antecipar a ocorrência da batalha dos Doze de Inglaterra e de entrar no jogo discursivo do protagonista, acompanhando detalhadamente as etapas de sua vida e os motivos que o levaram a entrar na defesa da dama desonrada. Isto efetivamente só acontecerá no final da primeira parte, já que, depois do embate, Álvaro Gonçalves Coutinho parte para a França, e não para Flandres, como indica a narrativa do Canto VI d'Os Lusíadas.

Ou seja, num cuidadoso e meticuloso jogo de um simulado passo a passo, o narrador vai sugerindo que toda a história de sua vida se desenvolve paralelamente aos eventos descritos por ele, e num itinerário muito diferente daquele registrado pelo cânone camoniano. E mesmo considerando esse paradoxo da narração como uma mais valia, um lucro para a arquitetura romanesca, não se poderá deixar de referendar que a categorização de "verdadeira história" só se justifica, porque a voz que a autentica é a do próprio dono das memórias narradas. Daí a importância do "Prólogo" do romance, onde o Magriço ostenta a sua carga de autenticidade, sem deixar de anunciar o leimotif central de sua empreitada na recuperação das suas aventuras e daqueles eventos por ele considerados principais:

\section{(Ano 1448 d.C.)}

No dizer de muitos sicofantas, eu, Álvaro Gonçalves Coutinho, sou um pobre diabo de reles intenções. Fizeram-me para a guerra e não vi outro mundo onde não fosse preciso erguer o punho, brandir uma arma, vociferar. Esta adaga, por exemplo, trago-a junto à cinta desde os nove anos e foi-me dada por meu Pai. Lembro-me bem, trouxe-a até à minha cama e disse-me: "Guarda-a sempre a jeito. Muitas vezes farás uso dela." Não mais a deixei, podendo com ela cortar tanto um melão como esquartejar um estafermo ou um homem. [...] Dentro de mim é maior o tormento do que a lhaneza, e não é uma nem duas as vezes que desperto de um sono como se me visse rodeado de algozes; e então penso na minha hora derradeira, cortado ao meio ou decepado num ermo qualquer sem nunca ter conhecido a paz, a não ser de relance, quando me rio de meu Pai e me vejo, como ele, um velho acometido de balbúrdias e achaques. [...] Ganhei soldos, jornas, tenças, por conta de Deus me ter valido com a sanha de não ter medo quando me atacam, mas não sei se é maior o medo de deixar este mundo sem nunca ter conhecido a paz no amor. (idem: 9-11)

Interessante observar que o protagonista indica uma consciência do seu papel, enquanto um agente secundário no curso da história oficial, ao assumir uma posição social desprivilegiada ("sou um pobre diabo de reles intenções"), sem qualquer tipo de favorecimento político. De certo modo, trazer a voz de uma personagem, cujas lacunas nem o texto camoniano e nem a sua fonte primária preenchem de forma suficiente, não deixa de instituir, mais uma vez, 
uma posição de interrogação do autor sobre certos estelionatos das narrativas canônicas. E vale frisar que isso não incide numa aposta desrespeitosa em relação às matrizes textuais, antes, parece mesmo uma proposta de continuação ou uma salutar complementação das narrativas já conhecidas, bem na esteira do que Teresa Cristina Cerdeira designa como "lacuna irreparável" (Cerdeira 2020: 87).

Pois exatamente com uma iniciativa de preencher as fissuras deixadas pelos versos camonianos, Tiago Salazar revisita o cânone para reinventar uma outra narrativa e com uma potente pretensão: a sua personagem emerge com o estatuto de protagonista, removendo, assim, as sombras do secundarismo e da coadjuvância que sobre si pairavam. Na verdade, ao possibilitar que o seu protagonista teça a sua própria história, Tiago Salazar cria um Magriço escritor, cujas revelações auxiliam na compreensão não só de sua época, mas também de nosso próprio tempo. Daí que a pequena nota introdutória ganha uma dimensão particular na cognição da trama romanesca e dos instrumentos nela aglutinados na sua construção:

A história não de todo contada (porque nunca de nada se pode contar o todo) dita pela voz de D. Álvaro Gonçalves Coutinho, mais conhecido por "O Magriço", valente guerrilheiro português, talvez um dos Doze de Inglaterra (treze, na verdade, se a história estiver bem contada). (Salazar 2020: 13; grifos meus)

Ao expor a incapacidade dos discursos canônicos em operar uma apreensão total da história, o ficcionista intervém com uma possibilidade de preenchimento de lacunas irreparáveis, feita em forma de uma hipótese ficcionalmente aceitável: a do ator principal assumir, agora, a voz do seu percurso. Além disso, inclui a maleabilidade dos discursos oficiais em assumirem mais de uma versão, já que o famoso episódio dos Doze de Inglaterra possui duas variantes: uma em que 11 cavaleiros seguem por mar e o Magriço por terra (a que, aliás, o próprio Luís de Camões utiliza) e outra em que 12 viajariam de navio até a Inglaterra, encontrando-se no duelo com o jovem Álvaro Coutinho (Basto 1986).

Ou seja, se os textos canônicos (o épico e o histórico) permitem uma liberdade divergente para a narração dos episódios passados, por que o ficcionista abdicaria de tal exercício, agora respaldado pela licença poética da ficção? Como o protagonista pretende dedicar-se a uma história bem contada, porque narrada por ele mesmo, o ator principal opta pela glosa divergente do épico camoniano e constrói a sua própria efabulação, não para negar a exposição do poeta quinhentista, mas para com ele estabelecer uma outra tradução da matéria narrada e permitir colocar nesta uma luz capaz de dissipar sombras.

Estabelecido, portanto, o jogo entre autor, leitor e matéria narrada, a movência e a dinâmica do Magriço são reveladas pela sua pena: "Ganhei soldos, jornas, tenças, por conta de Deus me ter valido com a sanha de não ter medo quando me atacam, mas não sei se é maior o medo de deixar este mundo sem nunca ter conhecido a paz no amor" (Salazar 2020: 11; grifos meus).

Já aqui, o leitor começa a dar conta de que o romance de Tiago Salazar expande alguns pressupostos do chamado romance histórico pós-moderno (Eco 1985; Marinho 1999), porque não se concentra apenas na recuperação irônica de uma matéria histórica, mas, ao lado dessa, 
Cadernos de Literatura Comparada

"Talvez um dos Doze de Inglaterra (treze, na verdade, se a história estiver bem contada)"

coteja outras categorias genológicas para a composição narrativa, a saber: 1) o Bildungsroman, porque, fazendo um balanço na velhice - "[...] quase a dobrar os sessenta anos" (Salazar 2020: 18), dirá o protagonista -, o Magriço decide "escrever as coisas como elas são" (idem: 17), antes que memória o traia. Ou seja, não deixa o texto em análise de recompor a "formação do jovem de família burguesa, seu desejo de aperfeiçoamento como indivíduo, mas também como classe" (Maas 2000: 13). Ainda que não se possa falar exatamente de uma consciência burguesa, em virtude do contexto cultural do século $\mathrm{XV}$, onde toda a ação se passa, não se poderá negar que, ao longo da exposição autodiegética, o Magriço não esconde uma preocupação cognitiva em explicitar a sua origem social e as consequências na sua vida; 2) o "romance de cavalaria", típico da literatura medieval, também surge nas malhas de $O$ Magriço, tendo em vista que nestas também se "espelha uma mundividência cortês e idealisticamente guerreira, estruturando-se a sua intriga em torno de duas isotopias fundamentais: o amor e a aventura" (Aguiar e Silva 1993: 673). Não à toa, a honrade e o espírito cavaleirescos constituem forças propulsoras na narrativa ("As façanhas sempre tiveram por detrás a coragem de muitos cujos nomes foram para sempre esquecidos"; Salazar 2020: 28), porque são elas que motivam o protagonista a tentar sair do estatuto de apagamento, tendo em vista que as suas façanhas e as suas aventuras são dignas de serem lembradas e eternizadas. Por outro lado, para além de romance histórico, de romance de formação e de romance de cavalaria, O Magriço não deixa de conter também uma dolorosa narrativa amorosa, de um afeto interrompido por intervenção familiar e real, gerando no protagonista uma reação feroz e fazendo-o vencer as suas próprias adversidades.

Na verdade, a singularidade do Magriço reside na sua condição de figura dissidente no cenário em que foi dado viver, tal como ele próprio irá reconhecer já no final da trama: "Os dissidentes como eu, que fugiam do rebanho para não se verem confundidos, tinham de se haver com a fama de logos" (idem: 171; grifos meus). Com um espírito tomado pela revolta diante das injustiças sobre si perpetradas, procura sempre soluções possíveis para extravasar a sua insatisfação. Por isso, muito diferente dos paradigmas físicos dos seus companheiros, ele enquadra-se como um dissidente físico, "magro como um espeto" com uma "estatura meã e a pequenez dos membros inferiores", com braços mais "compridos como os de um símio" (idem: 21-23). No entanto, o Magriço reconhece que essa precariedade física pode ser uma vantagem no seu ofício de cavaleiro:

Tinha um esqueleto de ferro, porquanto quase sempre saía de um tombo ou escaramuça com pouco mais do que uns arranhões de cada vez que ia ao chão.

As aparentes fraquezas eram as minhas forças e, se me desse para acreditar nos vaticínios proféticos de meu avô Vasco, era isto resultado de ter nascido de uma boa estrela. Até hoje nunca parti um osso ou rompi um tendão [...]. (idem: 23-24)

Também como um dissidente familiar, sofrendo a sina de ser o segundo filho, e não o primogênito, cedo aceita a prerrogativa de que caberia ao irmão mais velho, Vasco, "receber o quinhão de tudo o conquistado e amealhado" (idem: 44) pelo pai e pelo avô, cabendo-lhe, por- 
tanto, o destino solitário de um cavaleiro, continuando a linhagem de homens "tementes a Deus, obedientes ao rei e ao pai e reverentes ao nome" (ibidem).

Enquanto dissidente afetivo, vê seu amor por Isabel, filha do "novo meirinho-mor, D. Pedro Castro, senhor do Cadaval, destacado para a Beira por ordem expressa de El-Rei, para boa ordenança das justas causas" (idem: 46), ser recusado pela família da amada, pelo próprio pai e por D. João I, Mestre de Avis. Ao saber do destino mortal daquela que fora seu único amor, o protagonista reconhece ser essa a sina principal e o fator marcante na formação do seu espírito aguerrido e violento nas batalhas, canalizando a culpa naqueles que considerava responsáveis pelo seu infortúnio e transformando esse sentimento no segredo de sua força:

Tal como só vim a saber da malograda sorte de Isabel (e minha) pelo meu próprio Pai, que, tal como o meirinho exigiu, defendeu a sua clausura com o aval de El-Rei D. João. Tudo o que se passou a seguir ditaria o homem que viria a tornar-me.

Quando estava em guerras, largado por este mundo, muitos se perguntavam se o celibato era o segredo da minha força. Mantinha-me ocupado com outros afazeres como os de escorar as fraquezas dos inimigos e exercitar a espada como nos terreiros de Penedono ou Trancoso. Contudo, não passou um dia em que Isabel não me aparecesse em sonhos ou na vigília, e toda a beleza que vi, era nela que logo pensava, não me achando digno de ter o que não lhe pudesse confiar. Por isso, muitos tolhi vendo neles a cabeça de seu famigerado pai, do meu e até de El-Rei. (idem: 48-49)

Ainda, nesse encargo, revela o seu lado dissidente no ofício cavaleiresco, já que a sua formação, muito singular para a própria época, reside no somatório da prática dos treinos e das simulações das disputas e batalhas, com o "costume de ler" (idem: 29). Assim, devora as andanças de Amadis, as vidas dos Santos, os amores de Tristão e Isolda, as aventuras dos Cavaleiros da Távola Redonda, o Livro de Montaria de D. João I, o Livro de Ensinança de Bem Cavalgar Toda Sela, o Leal Conselheiro e o Livro dos Conselhos de D. Duarte, além de todo um repertório disponível "no tombo, na Biblioteca do Paço, nas aulas com os mestres ou em cada solar e castelo" (idem: 31) por onde passa. Apesar de reconhecer a utilidade dessa bagagem na sua formação como cavaleiro, o narrador consegue distinguir e separar a "longa distância entre o escrito e o vivido" (idem: 33), não caindo, portanto, na imersão de um mundo fantasioso, e mantendo a sua percepção do mundo, das pessoas e da ordem sócio-política do seu tempo sempre aguçada: "Em boa verdade, aprendi sempre mais com o que via e fazia do que ensinado por livros e conselhos" (idem: 34).

Ora, na verdade, gosto de pensar que essas dissidências do Magriço constituem uma bem urdida estratégia metanarrativa, engendrada por Tiago Salazar. A prática de leitura das principais obras produzidas na sua época dá ao protagonista uma consciência crítica dos elementos constitutivos dos textos lidos, chegando mesmo ao ponto de levantar hipóteses e conjecturas diante daquilo que não está explicitado nos respectivos conteúdos. Não gratuitamente, é com o Bosco Deleitoso e com o Horto do Esposo, que Álvaro Gonçalves Coutinho lança perguntas inquietantes e que pesam sobre as sombras deixadas ao longo dos dois volumes: 
Cadernos de Literatura Comparada

"Talvez um dos Doze de Inglaterra (treze, na verdade, se a história estiver bem contada)"

Muitas questões se me levantavam, como no Horto do Esposo e no Bosco Deleitoso, de onde partiam os cavaleiros para as Cruzadas. Imbuídos de que espírito? Não podiam antes querer estes deixar-se ficar por casa, cuidando da sua horta e dos seus, ou temiam que, se o fizessem assim, os tomassem por fracos? E é mais forte ou fraco o que parte para a guerra ou o que defende o seu exército? Defendia no Horto o autor, um monge de quem se não sabe o nome, e que havia de ter lido Petrarca e o ascético Bernardo de Claraval, a renúncia aos bens terrenos e aos prazeres mundanos associados à Fortuna, elogiando a contemplação e a busca pessoal da salvação e da verdade eterna. Essa busca também eu a sentira, e mais sentia agora no aro, consolado de uma pequena horta, uma centena de hectares que me davam bom vinho e o dinheiro suficiente para não me apoquentar. (idem: 31-32)

Há, aqui, um ponto crucial para compreender a aproximação de Tiago Salazar à matéria histórico-literária apropriada para o enredo de seu 0 Magriço. Toda a inquietação narrada pelo protagonista expõe um dado sintomático para o entendimento não só do objeto interno (a própria narrativa das aventuras e dos dissabores de Álvaro Gonçalves Coutinho), mas também, e sobretudo, do objeto externo (o próprio romance de Tiago Salazar na sua materialidade física e textual).

De um lado, tal como mais a frente se verá, esse questionamento é um instrumento importante para o Magriço, sobretudo, quando, mais tarde, confronta El-Rei e o pai, sobre o impedimento do seu casamento com Isabel. De outro, não serão também essas as artimanhas de Tiago Salazar (criador de um outro Magriço), tão inquiridor e interpelativo como a sua própria criatura? Não será o gesto do Magriço de levantar questões um exercício especular do espírito criador do romancista português contemporâneo? E, assim fazendo, não estabelece este uma revisitação a narrativa épica de Luís de Camões, direcionando para a personagem do episódio dos Doze de Inglaterra, no Canto VI de Os Lusíadas, os mesmos questionamentos? Afinal, qual a trajetória inicial de Álvaro Gonçalves Coutinho? Por que a sua insistência em não ir diretamente de navio com os demais companheiros? Qual o seu destino e o seu desfecho depois da batalha em terras britânicas?

Se é certo que o poema épico não se detém nessas questões, por razões óbvias de concentração nos feitos heroicos coletivos e não exatamente na individualidade dos seus atores, não fará o romance de Tiago Salazar de todas essas lacunas uma espécie de motivação para o seu ato efabulador? Acredito que sim, tendo em vista, sobretudo, a revisitação operada sobre o conhecido episódio da épica camoniana e a iniciativa de reinventar uma outra narrativa possível, sem excluir as motivações mais específicas de seu protagonista e sem apagar ou maquiar os seus defeitos. Por mais de uma vez, o narrador-protagonista deixa indícios desta necessidade:

Um homem que se ponha a falar de si, se o fizer em honestidade e tino, não pode esconder as suas deformidades, e quem dele falar como um valioso guerreiro ou santo imaculado que o faça no seu próprio juízo, sem ocultar as fraquezas que teve, porque todos as têm. (idem: 25) 
Pois, ao dar-me a mim para escrever, não tinha por intenção esconder as minhas vergonhas, que não eram poucas, nem fazer-me passar por erudito, falando dos livros que lera. Era forte a paixão da leitura, imaginando nas histórias o que me esperava, mas não tanto como veio a ser a de combater e galgar terras. Podia aprender nos livros, mas, se não acreditava numa só palavra que nalgum deles lia, suspeitando-o por ter vivido de coisas fantasiosas que neles se contavam, sobretudo das guerras e rixas, o que fazia era pô-lo de lado e blasfemar sobre o logro do seu autor. Havia de ser mais louvável o que mal escrevesse, mas fosse sincero, do que aquele que muito bem ornasse o seu discurso, não pondo nele coisa digna de contar por nada daquilo ter sido sentido ou vivido. (idem: 30 )

Os meus bem-aventurados dias de cavaleiro tinham os dias contados, restando-me apenas mostrar as coisas como as vivera, na forma escrita, se a tanto me ajudasse o engenho e a arte que tinha para as armas. (idem: 146$)$

Por fim, mas não menos importante, outras duas dissidências reverberam na composição do protagonista. O seu caráter de viajante dissidente, abdicando do trajeto direto por mar até a Inglaterra, para fazer o percurso mais longo: por terra até Calais, na companhia do seu escudeiro Rodrigo e de seu cavalo Passo Preto, e de lá até à Inglaterra, atravessando de barco apenas o Canal da Mancha.

Mais uma vez, ao revés dos versos camonianos, que apontam como justificativa o desejo do Magriço de "andar terras estranhas, / Por ver mais águas que as do Douro e Tejo, / Várias gentes e leis e várias manhas" (Camões 2011: 232), o romance de Tiago Salazar revela um protagonista muito diferente, porque fiel ao seu projeto de escrita, sobretudo, em não esconder o real motivo de sua recusa a uma longa viagem por mar: a sua incapacidade para o espírito marinheiro e a sua indisposição para enfrentar uma longa travessia de barco, ainda que isso pudesse ser interpretado como uma fraqueza:

Aquilo que faz empolgantes as viagens e as histórias estaria mais reservado para o outro lado do canal, a começar pelas emoções que me consumiram na breve passagem de Calais até um porto inglês, cujo nome me escapa, e que me pareceu uma eternidade. Dei por mim zaranzo assim que zarpámos e, ainda o mar não se encapelara, a vomitar as entranhas borda fora acocorado sobre a amurada, e a jurar nunca mais me ver embarcado, sabendo que ainda teria a viagem de volta e para mal dos meus pecados não havendo como a fazer por terra firme. (Salazar 2020: 97)

Toda essa cena confessional do mal-estar do protagonista não deixa de ser importante, posto que, se por um lado, revela a indisposição e a fraqueza física para o mar, por outro, não apaga a coragem e o destemor diante do desafio da batalha. Por isso, ao declinar da valorização épica das qualidades heróicas, tal como se percebe no episódio da epopeia camoniana, na trama romanesca de $\mathrm{O}$ Magriço, o narrador-protagonista prefere uma aproximação maior com as qualidades humanas, seja as negativas, seja as positivas. Talvez, por isso, cause surpresa o contraste desta cena com a seguinte, na culminância do duelo: 
Cadernos de Literatura Comparada

"Talvez um dos Doze de Inglaterra (treze, na verdade, se a história estiver bem contada)"

Tinha dito a meus consócios, e fui sempre de honrar a minha palavra, estar onde era chamado ao dia e hora certos. Quando galopei Passo Preto, também ele ornado de saiote de guerra, saído de uma floresta directo ao terreiro do duelo, dei por eles já em peleja, e pior, a serem mutilados. Mal me viram entrar pelo terreiro, desatou um alvoroço, interrompeu-se o duelo e ajuntaram-se todos a mim, aos gritos e abraçados. Alguns eram já feridos, porém, ao verem-me, renasciam e tornavam. Nos palanques, como num teatro ou circo romano, estava o rei inglês e toda a Corte, e as damas, onze delas vestidas de cores e sedas, de ouro e jóias, ricas e ledas, e, entre as onze, uma mais toda trajada de negro, de rosto cabisbaixo e oculto num xaile. [...] Tudo se passou então como é próprio das batalhas ou duelos, que duram até onde durarem, isto é, enquanto haja um vivo e de pé para contar a história. O estrépito dos cavalos, o feroz semblante, os áureos freios, o sol a rutilar nas armas, o chão todo a tremer, o estremecer do coração, a pele e os músculos retesados, a cabeça a latejar, um único e vago pensamento que é matar ou morrer, os gemidos, os gritos, as armas antes de prata reluzente ensanguentadas, os açoites na montada, o voo e a queda, os penachos do elmo, o pavor e a coragem, a soberba e a derrota, tudo o que pode ser dito e traduzido por palavras, desvanece-se no intervalo que dura a peleja. Matei o meu opositor cortando-lhe a cabeça como a um nabo, e mais a metade dos deles foram mortos por meus consócios, ficando o terreiro numa papa de lama e sangue e membros decepados, as armas partidas como cristais, os cavalos tresmalhados. Deu-se por terminado o duelo ao som de um clarim. O rei e as damas ergueram-se em loas, e os cavaleiros ingleses sobrevivos largaram dali pelo campo afora, de viseiras e espadas e lanças ao baixo. Estava vingado o fero desafio e vingada a honra e cumprida a missão a que nos prometêramos. (idem: 99-100)

Toda essa sequência com uma impressionante dinâmica cinematográfica - desde os movimentos dos combatentes, sobretudo os do Magriço, a forma com que este desfere o golpe fatal no seu inimigo, até o barulho vindo dos atritos das armas, os gritos dos espectadores nos palanques e o término decretado pelo ressoar de um clarim - estampa um vigor intertextual com a mesma cena no Canto VI de Os Lusíadas (Camões 2011: 234-236), mas também dela se distingue pela forma com que capta e descreve os efeitos sonoros de diferentes fontes (vide na cena anterior os cavalos, as armas e o público, por exemplo), além dos ritmos acelerados dos batimentos cardíacos dos atores e as reações frenéticas do público e dos cavaleiros portugueses ao perceberem concluída a vingança e restaurada a honra das doze damas.

No meu entender, longe de recusar o texto camoniano, o romance de Tiago Salazar faz uma sensível homenagem ao autor e ao texto que, indiscutivelmente, compõem as fontes basilares do seu romance. No entanto, a diferença marcante do duelo no romance incide desde a travessia do protagonista pelo Canal da Mancha até a sua chegada no campo de batalha. Comparadas essas duas cenas, a primeira desnuda uma fraqueza do protagonista, entendida, aqui, como uma dissidência do seu espírito viajante, mas é exatamente ela que acaba por sublinhar um outro aspecto singular do Magriço: o de dissidente político. Tal diferença ecoa ao longo do seu percurso, estando também ligada à dissidência afetiva, como reiteradamente o narrador tenta expressar: "Lutava por conquistar um lugar e uma posição que chegavam fruto da minha bravura, mas teimava em não me perdoar ter deixado escapar o ouro do amor por entre os dedos" (Salazar 2020: 117). 
Na verdade, a posterior ida de Magriço para a França, numa nova etapa de aventuras, que inclui a prisão, a tortura pelos inimigos de Armagnac, seguidas do seu resgate pelos cavaleiros borgonheses, forma um conjunto importante de ações na sua formação e no seu amadurecimento. Tanto assim é que, somente com o encontro com Thomaz de Noronha e Estevão Perez de Andrada, cavaleiros portugueses em visita à corte de Borgonha, Álvaro Coutinho considera a possibilidade de retornar ao país natal, não sem antes revelar a amargura que ainda carrega, força motriz de sua própria condição de dissidente:

Deixava a Borgonha e os franceses grato por tantas e tamanhas peripécias, acima de todos a João Sem Medo, que me havia feito seu chambelain, e tantas honras e reconhecimentos me dera. E, se nem sempre lhe sorri com a vitória em todas as alturas que o servi, em justa, batalha, agravo ou diferendo, tudo fiz por a obter, e quem ouse denegri-lo na sua majestosa virtude até ao fim dos meus dias comigo terá de se haver. Já se sabe que a verdade nunca é certeira como um tiro de arco ou besta, por serem os homens mais dados ao exagero, à deturpação e mesmo à mentira do que ao rigor e ponderação. Os poucos que aqui vou louvando e enchendo de méritos, porque a mim me tocaram, para outros não passarão de invios. Nem os santos passam por esta terra imaculados. Olhe-se para onde se olhar e é mais o rasto de miséria do que de grandeza, e muitos são os grandes que morrem sem terem sido reconhecidos. (idem: 144)

Tal como o trecho acima demonstra, a grande questão para o Magriço reside exatamente na autoconsciência de seu posicionamento ético diante dos sentimentos que defende e das idéias nas quais acredita. Por isso, acredito que, mais do que arquitetar um super-cavaleiro com uma potencialidade feroz para a brutalidade, Tiago Salazar revisita o herói dos versos camonianos e reinventa-o nas suas malhas ficcionais, enquanto uma personagem autoconsciente do seu estatuto social de cavaleiro, de homem de palavra e de honra e, acima de tudo, de "apenas um homem a quem havia sido decretado o crime de querer viver um amor proibido" (ibidem). Em outras palavras: um homem comum inconformado de ter o seu livre arbítrio roubado e censurado, marcado profundamente por desgosto amoroso. Nesse sentido, ainda que difira da personagem camoniana, não estabelece, aqui, o Magriço de Tiago Salazar uma aliança muito convergente com alguns versos da lírica camoniana: "Amor, co a esperança já perdida, / teu soberano templo visitei; / por sinal do naufrágio que passei, / em lugar dos vestidos, pus a vida" (Camões 1988: 98)?

Distinto, porém aberto a consonâncias com a pena camoniana, o Magriço de Tiago Salazar é um homem movido por princípios éticos inabaláveis, capaz inclusive de enfrentar as principais figuras do poder na sua época, sobretudo, quando esse confronto é para buscar uma explicação exata por ter sua liberdade amorosa roubada. Por isso, muitas cenas posteriores ao duelo nos campos ingleses só poderiam ganhar vida graças à licença poética da fição em investir nessa faceta dissidente do Magriço, capaz de encarar as principais forças políticas do seu tempo em nome de uma explicação justa, direta e honesta.

Assim, por exemplo, dá-se o confronto com D. João I:

- Meu Senhor, como poderei dizer-vos da angústia que trago comigo e que sinto devida a Vós, sem que 
Cadernos de Literatura Comparada

"Talvez um dos Doze de Inglaterra (treze, na verdade, se a história estiver bem contada)"

isto vos ofenda?

- Dizei-o simplesmente, meu filho, e não temais se não vos saírem as palavras com brandura.

- A vossa decisão, certamente lembrai-vos dela?!

- De não consentir no vosso casamento com Isabel?

- Sim, meu Senhor. Pois nunca nestes anos me consegui libertar da mágoa de Vossa decisão e, antes da Vossa, da de meu Pai, a quem terei de dizer o mesmo que agora Vos digo. [...]

- Ao privar-vos de um amor, não foi por não respeitar o amor que lhe consagraste. Foi por termos reservados para vós os maiores desígnios. Os nossos maiores combatentes não foram homens tíbios. [...] - Meu Senhor, são conhecidas as vossas muitas virtudes e de como é de cima que deve vir o exemplo. Hoje, ao ouvi-lo de viva voz, tudo me parece fazer mais sentido, e estou certo de que deverei o mesmo dizer a meu Pai, que ainda não perdoei por semelhante feito. (idem: 149-150)

E, depois, no último dialogo trocado com seu pai:

- Nunca neste anos todos percebi porque me foi tirada a vontade de decidir pelo meu coração o que era melhor para mim.

- O coração só serve para nos manter vivos e nos dar coragem, devias sabê-lo, sendo tu um Coutinho.

[...] Queres saber porque nos opusemos, eu e nosso Rei, contra a tua vontade.

- É meu direito.

- Se te tivesse sido concedido esse casamento, não terias feito o que te estava prometido. [...]

- Comove-me a vossa sinceridade, mas não queria deixar de vos dizer que essa é a ferida mais funda que alguma vez me infligiram. E devo-a a vós, e a El-Rei. (idem: 154)

Ainda que as explicações dadas pelo rei e pelo pai sejam respaldadas por uma necessidade de talhar o destino de um guerreiro destemido, a questão crucial desencadeadora de toda a tensão entre as três personagens é o valor ético inequívoco de Magriço, que não abre mão de reclamar pela sua liberdade cerceada e desafiar as autoridades real e paterna, já que, mais velho, pondera que sempre demonstrara ser um homem de honra e de palavra. Aliás, nessa mesma fase madura do protagonista, muitos são os aforismos e os pensamentos lançados por ele que confirmam essa sua linha de agir.

Não gratuitamente, antes de expor as artimanhas tecidas por concorrentes invejosos seus na corte de Dom João, o próprio Magriço antecipa as cenas de desconcerto, quando se depara com as disputas medíocres dos cortesãos, com os jogos de bajulação ao poder e com as armadilhas tecidas pela inveja alheia. Desse modo, declara o narrador: "Tudo se vende, menos a virtude e a honra, e não as vendi à sorrelfa como me vieram uns pategos tentar" (idem: 164). Ao que tudo indica, o protagonista vivencia o desconcerto do mundo camoniano, e sofre as consequências por não compactuar com "a falsidade, o abuso, as injustiças" (idem: 180), resignando-se em aceitar "as moléstias como os contentamentos, que são ambos de pouca dura" (ibidem).

Assim, levando até as últimas consequências aquele "paradoxo da narração" (Glowinski 
1977: 105), o narrador-protagonista vai cautelosamente concluindo o passo a passo discursivo da sua "autobiografia fictícia" (Marinho 1999: 215). De forma muito inteligente, Tiago Salazar parece encaminhar a resolução desse paradoxo, ao criar um contador e escritor que, somadas todas as etapas de vida relatadas, chama para si aquelas duas "famílias de narradores" (Benjamin 1985: 199) benjaminianos: enquanto cavaleiro e guerreiro, o Magriço assume a voz do "marinheiro comerciante" (ibidem), porque a matéria é fruto dos seus deslocamentos em virtude do seu ofício; já como cultivador de vinhedos estabelecido na região do Alentejo, exerce a perspectiva do "trabalhador sedentário" (ibidem), relembrando fábulas e ditados que ouvira de sua avó Beatriz e do seu pai, não deixando, agora, de tecer ele mesmo os seus aforismos e suas máximas.

Nesse sentido, compreende-se o desfecho de Magriço na região de Reguengos, como um agricultor e um mercador, afastando-se das mediocridades cortesãs. Ali, prospera como comerciante, encontra uma nova oportunidade de amar com Maria, com quem se casa, e acompanha de longe as mudanças dos reis no trono de Portugal: D. João I (19385-1433), D. Duarte (1433-1438), Regente D. Pedro (1438-1447) e D. Afonso V (1448-1481). No reinado deste último, constata-se a causa do seu isolamento definitivo: "[...] a peste voltou com forças malignas nunca antes vistas no Reino" (idem: 186).

Exatamente nesse cenário distópico de peste pela Europa, Magriço impõe-se uma reclusão de eremita, deixando Maria com a casa e os vinhedos. Na sua confiança em ter "mais crença do que fé de que um mal, tal como um bem, nunca perduram" (idem: 186), acaba por passar por mais uma perda, quando se dá conta de que a sua atitude de "a ter deixado ali, a seu inteiro cuidado, achando estar a protegê-la, mas desvalendo-a” (idem: 187), foi a causa da sua própria desgraça.

Na verdade, a morte de Maria expõe a simplicidade de um "homem como outro qualquer; beirão, bruto, a quem o amor maduro chegara tarde" (idem: 179), cuja principal inquietação, na verdade, foi ter a sua escolha do coração impedida e estancada por figuras correspondentes ao poder, e nunca ter se conformado com essa censura. Daí que a sua última sentença, a sua derradeira auto-imagem é exatamente essa, a de um homem amargurado na sua capacidade de amar: "Perdia assim, a segunda vez, o amor, que é a maior virtude e nada se lhe iguala" (idem: 187).

Não deixa de ser interessante este recurso na composição do protagonista, porque, se como apontei, o Magriço tende a se distinguir do seu homônimo no episódio épico de Camões, em muitos momentos, como o do desencanto amoroso e, também, o do final de sua trajetória, preocupado em tudo colocar no papel, é preciso sublinhar a forma sensível com que Tiago Salazar opera flagrantes aproximações com a lírica camoniana. Não será difícil, portanto, perceber nas entrelinhas das confissões do Magriço ("Tudo isto me passou ao lado e só o conto para que tenhais em mente como, na vida, pouco ou nada se mantém puro"; idem: 185) o mesmo desencanto com o desconcerto do mundo, tão insistente nos sonetos camonianos:

Oh, como se me alonga, de ano em ano, 
Cadernos de Literatura Comparada

"Talvez um dos Doze de Inglaterra (treze, na verdade, se a história estiver bem contada)"

\author{
A peregrinação cansada minha! \\ Como se encurta, e como ao fim caminha \\ Este meu breve e vão discurso humano! \\ Vai-se gastando a idade e cresce o dano; \\ Perde-se-me um remédio, que inda tinha; \\ Se por experiência se adivinha, \\ Qualquer grande esperança é grande engano. (Camões 1988: 91)
}

Se Tiago Salazar revisita os versos d'Os Lusíadas e ousa reinventar um outro Magriço, mais humano, mais exposto nos seus defeitos, mais desconcertado com as vicissitudes do mundo, mais aberto a confessar o seu tormento amoroso, e, por isso, muito próximo das angústias e dos desassossegos característicos da lírica camoniana, quero crer que tal aposta, para além de preencher lacunas de um tempo passado, pode também contribuir para uma profunda reflexão dos leitores sobre o seu próprio presente. Em tempos atuais de ambientes cindidos por uma pandemia (outra peste?) que a todos assusta e impõe um isolamento social, a fábula de 0 Magriço compõe não apenas uma revisitação ao cânone camoniano, mas também sugere uma possibilidade de reinventar outras narrativas, sem abandonar algumas lições muito caras à nossa contemporaneidade: a crença numa ética em que o indivíduo seja capaz de concretizar as suas escolhas sem restrições ou impedimentos.

Nesse sentido, gosto de pensar que a efabulação de O Magriço, de Tiago Salazar, se desenha também de forma alegórica, tal como proposta por Mário César Lugarinho, para quem "a Literatura percebida como alegoria, é, sobretudo, o lugar onde se inscreve a História dos vencidos, a História dos silenciados, a História não contada, a História dos oprimidos que contestaram o poder" (Lugarinho 2005: 30).

Ainda que a personagem Álvaro Gonçalves Coutinho não se enquadre especificamente como um vencido e mesmo um oprimido, já que faz parte de uma elite bélica cavaleiresca marcada pelo sucesso e pela vitória, fico a me interrogar se a maneira como o narrador-protagonista se posiciona, em nítido confronto com o rei e o pai, figurações dos poderes daquele contexto epocal, não poderá ser entendida como uma forma de o Magriço exorcizar os seus fantasmas e se liberar definitivamente de tudo aquilo que o aprisiona às classes dominantes do seu tempo, conferindo, assim, um "outro sentido ao passado" (idem: 31)? Não será o feitio da censura e do silenciamento do seu amor por Isabel e da sua liberdade afetiva modelo outro de opressão? E, sobretudo, não poderão as sombras e as lacunas que sobre a sua trajetória se colocaram e a exposição de uma simplicidade na sua maneira de ser e estar no mundo ser entendidas como estratégias de uma fábula alegórica para a nossa própria contemporaneidade?

Acredito que, com O Magriço, Tiago Salazar propõe, com a licença poética da ficção, a máxima de que, apesar das contrariedades, dos abusos e das injustiças, a capacidade de não abrir mão dos seus desejos e dos seus sentimentos constitui o valor maior a ser defendido. Afinal, nas sábias palavras do seu protagonista, que parecem estar também dirigidas a nós, leitores 
do século XXI, como um autêntico alerta: "Quem nos garante que, daqui a um par de séculos, não estejamos esquecidos ou tomados pela ganância, como todos os que aspiram ao poder?" (Salazar 2020: 168).

\section{NOTAS}

* Jorge Vicente Valentim é Doutor em Letras Vernáculas (Literatura Portuguesa) pela Faculdade de Letras da UFRJ. Professor Associado de Literaturas de Língua Portuguesa (Literatura Portuguesa e Literaturas Africanas de Língua Portuguesa) do Departamento de Letras e Professor Permanente do Programa de Pós-Graduação em Estudos de Literatura da UFSCar, onde também coordena o GELPA (Grupo de Pesquisa de Estudos Literários Portugueses e Africanos). Vice-Presidente da ABRAPLIP (Associação Brasileira de Professores de Literatura Portuguesa), nas Gestões 2016-2017 e 2020-2021. Autor de ensaios e obras críticas no Brasil e no exterior, em 2017, foi finalista do Prêmio Jabuti, com "Corpo no outro corpo": homoerotismo na narrativa portuguesa contemporânea (São Carlos: EdUFSCar, 2016), resultado de investigação de Pós-Doutoramento, realizada na FLUP, sob a supervisão da Profa. Dra. Isabel Pires de Lima.

${ }^{1}$ Vale mencionar, nesse sentido, o pontual e muito interessante verbete de Marcia Arruda Franco, no Dicionário de Luís de Camões (2011), quando reitera a condição canônica do poeta quinhentista e da capital obra épica, já na sua época: "Entre o século XVI e meados do século XVII, a canonização se justificou pelo louvor do trabalho, levado a cabo na épica de Camões, de dignificação e de ilustração da língua portuguesa. Os Lusíadas, figurando no cânone das grandes épicas da cultura ocidental, em linha com a Odisseia e a Eneida, depressa conferiram dignidade e crédito à língua portuguesa como língua de cultura" (Franco 2011: 219, grifos meus).

${ }^{2}$ Nascido em Lisboa, em 1972, Tiago Salazar é formado em Relações Internacionais, além de ter estudado Guionismo e Dramaturgia em Londres. Atualmente, é doutorando no Instituto de Geografia, onde prepara uma tese sobre A volta ao mundo, de Ferreira de Castro. Como jornalista, venceu o prémio Jovem Repórter do Centro Nacional de Cultura, em 1995. Foi Bolseiro da Fundação Luso Americana em Washington, em 2010, e vencedor do prémio Literatura na XVII Gala dos prémios da revista Mais Alentejo, em 2018. Como autor, é um dos mais significativos nomes da geração dos novíssimos ficcionistas portugueses (aqueles que aparecem na cena literária a partir dos anos 2000), tendo iniciado sua trajetória com Viagens Sentimentais (2007). A partir daí, vem publicando outras narrativas de viagem, diário, crônica, teatro, literatura infanto-juvenil e romance, dentre os quais As rotas do sonho (2010), Hei-de amar-te mais (2013), Crónica da selva (2014), O baú contador de histórias (2014), A escada de Istambul (2016), A orelha negra (2017) e O magriço (2020), sua estréia no género do romance histórico.

${ }^{3}$ Doravante, sempre que as referências forem direcionadas ao citado romance, a expressão virá em itálico (O Magriço). Quando não grafada assim, ela se refere ao protagonista homônimo (Álvaro Gonçalves Coutinho - o Magriço), personagem principal da obra em análise. 


\section{Bibliografia}

Aguiar e Silva, Vítor Manuel (1993), Teoria da literatura, $8^{\mathrm{a}}$ edição, Coimbra, Almedina.

Arnaut, Ana Paula (2002), Post-Modernismo no romance português contemporâneo: fios de Ariadne - máscaras de Proteu, Coimbra, Almedina.

Basto, A. de Magalhães (1986), O essencial sobre Os Doze de Inglaterra, Lisboa, Imprensa Nacional - Casa da Moeda.

Benjamin, Walter (1985), Magia e técnica, arte e política. Ensaios sobre literatura e história da cultura, $4^{\mathrm{a}}$. edição, tradução de Sérgio Paulo Rouanet, São Paulo, Brasiliense.

Camões, Luís de (2011), Os Lusíadas, edição organizada por Emanuel Paulo Ramos, Porto, Porto Editora.

Cerdeira, Teresa Cristina (2020), Formas de ler, Belo Horizonte, Moinhos.

Eco, Umberto (1985), Pós-escrito a 'O nome da rosa', tradução de Letizia Zini Antunes e Álvaro Lorencini, Rio de Janeiro, Nova Fronteira.

Ferro, Manuel (2011), "Episódio dos Doze de Inglaterra", in Aguiar e Silva, Vítor (coord.) (2011), Dicionário de Luís de Camões, São Paulo, Leya, p. 318-322.

Franco, Márcia Arruda (2011), "O cânone literário português e Camões", in Aguiar e Silva, Vítor (coord.) (2011), Dicionário de Luís de Camões, São Paulo, Leya, p. 219-228.

Ginzburg, Carlos (1987), o queijo e os vermes. O cotidiano e as idéias de um moleiro perseguido pela inquisição, tradução de Maria Betânia Amoroso, São Paulo, Companhia das Letras.

Glowinski, Michal (1977), "On the first-person novel", New Literary History, vol. 9, no. 1, p. 103-114.<https://www.jstor.org/stable/468439?read-now=1\&refreqid=excelsior\%3A14e 08e23c166b019e536b2d71cd2c36f\&seq=1\#page_scan_tab_contents > último acesso em 27 de dezembro de 2020.

Gobbi, Márcia Valéria Zambonni (2011), A ficcionalização da história: mito e paródia na narrativa portuguesa contemporânea, São Paulo, Editora da UNESP.

Lugarinho, Mário César (2005), Manuel Alegre: mito, memória e utopia, Lisboa, Edições Colibri. Salazar, Tiago (2020), O Magriço. A verdadeira história de D. Álvaro Gonçalves Coutinho, um dos Doze de Inglaterra. Lisboa: Oficina do Livro, 2020.

Saramago, José (2011), 0 ano da morte de Ricardo Reis, São Paulo, Companhia das Letras. 